\title{
Niabella aurantiaca gen. nov., sp. nov., isolated from a greenhouse soil in Korea
}

Correspondence
Soon-Wo Kwon
swkwon@rda.go.kr Byung-Yong Kim, ${ }^{1}$ Hang-Yeon Weon, ${ }^{2}$ Seung-Hee Yoo, ${ }^{1}$ Seung-Beom Hong, ${ }^{1}$ Soon-Wo Kwon, ${ }^{1}$ Erko Stackebrandt ${ }^{3}$ and Seung-Joo Go

\author{
${ }^{1}$ Korean Agricultural Culture Collection (KACC), Microbial Genetics Division, National Institute \\ of Agricultural Biotechnology, Rural Development Administration, Suwon 441-707, Korea \\ ${ }^{2}$ Applied Microbiology Division, National Institute of Agricultural Science and Technology, Rural \\ Development Administration, Suwon 441-707, Korea \\ ${ }^{3}$ Deutsche Sammlung von Mikroorganismen und Zellkulturen $\mathrm{GmbH}$, Mascheroder Weg $1 \mathrm{~b}$, \\ D-38124 Braunschweig, Germany
}

\begin{abstract}
An orange-coloured bacterial strain, designated $\mathrm{R} 2 \mathrm{~A} 15-11^{\top}$, was isolated from greenhouse soil. The strain was found to be strictly aerobic, Gram-negative, non-spore-forming and non-flagellated. The cells were short rods $(0.7-0.9 \times 1.0-1.5 \mu \mathrm{m})$ and produced flexirubin. Growth of the strain was observed at $10-35{ }^{\circ} \mathrm{C}, \mathrm{pH} 5.0-8.0$ and $0-3 \%(\mathrm{w} / \mathrm{v}) \mathrm{NaCl}$. The predominant isoprenoid quinone was MK-7. The major fatty acids were iso- $C_{15: 0}$, iso- $C_{15: 1} G$, iso- $C_{17: 0} 3-O H$ and summed feature 3 (comprising iso- $\mathrm{C}_{15: 0} 2-\mathrm{OH}$ and/or $\mathrm{C}_{16: 1} \omega 7 \mathrm{c}$ ). The genomic DNA G+C content was 45.0 mol\%. Phylogenetic analysis of the 16S rRNA gene sequence of strain R2A $15-11^{\top}$ revealed a clear affiliation with the phylum Bacteroidetes, and the highest levels of sequence similarity were found with respect to Terrimonas ferruginea ATCC $13524^{\top}(91.5 \%)$, Terrimonas lutea DY' (90.2\%), Niastella yeongjuensis GR20-13 ${ }^{\top}(89.9 \%)$ and Niastella koreensis GR20-10 $10^{\top}$ (89.7\%). On the basis of the polyphasic evidence from this study, strain R2A $15-11^{\top}$ represents a novel genus and species, for which the name Niabella aurantiaca gen. nov., sp. nov. is proposed. The type strain of Niabella aurantiaca is R2A15-11 ${ }^{\top}$ (=KACC $11698^{\top}=$ DSM $17617^{\top}$ ).
\end{abstract}

Although the taxonomic relationships among species within the genera Flavobacterium, Flexibacter and Cytophaga have been largely resolved through phylogenetic analysis (Sly et al., 1999; Nakagawa \& Yamasato, 1993; Nakagawa et al., 2002), these genera remain taxonomically heterogeneous. The genus Terrimonas (Xie \& Yokota, 2006) was recently proposed for the misclassified species Flavobacterium ferrugineum and a novel garden-soil isolate. A second recently described genus, Niastella, was created for isolates from Korean ginseng fields (Weon et al., 2006).

We isolated a bacterial strain, designated R2A15-11 ${ }^{\mathrm{T}}$, from greenhouse soil, and found it to be related to members of the genera Terrimonas and Niastella. The soil sample was obtained from a greenhouse cultivated with lettuce (Lactuca sativa L.) in the Yeoju region of Korea. The sample was serially diluted with $0.85 \% \mathrm{NaCl}(\mathrm{w} / \mathrm{v})$ and the dilutions

The GenBank/EMBL/DDBJ accession number for the 16S rRNA gene sequence of strain R2A15-11 ${ }^{\top}$ is DQ457019.

The cellular fatty acid compositions of strain R2A $15-11^{\top}$ and related strains are available in a supplementary table in IJSEM Online. plated onto R2A agar (Difco). The strain was isolated after incubation for 4 days at $28^{\circ} \mathrm{C}$.

The cell morphology of cells grown on R2A for 2 days was examined by transmission electron microscopy (Fig. 1), using cells negatively stained with $0.5 \%$ uranyl acetate. Gliding motility was investigated by using oil-immersion phase-contrast microscopy of the edges of colonies when the cells were in the exponential phase of growth. Growth at different temperatures and $\mathrm{pHs}$ was tested at $5-45^{\circ} \mathrm{C}$ (in increments of $5^{\circ} \mathrm{C}$ ) and $\mathrm{pH} 4-10$ (in increments of $1 \mathrm{pH}$ unit), respectively. Salt tolerance was tested on R2A broth supplemented with $0,1,2,3,5$ and $7 \%(w / v) ~ \mathrm{NaCl}$. Gram staining, catalase activity, cytochrome oxidase activity and the hydrolysis of alginic acid, carboxymethylcellulose, casein, chitin (from crab shells), DNA, starch and tyrosine were investigated according to the methods of Smibert \& Krieg (1994). Flexirubin pigment was detected by means of a colour shift after exposure to a $20 \%(\mathrm{w} / \mathrm{v}) \mathrm{KOH}$ solution (Reichenbach, 1992). Other biochemical tests were carried out by using API 20NE, API ID 32 GN and API ZYM test kits according to the instructions of the manufacturer (bioMérieux). 


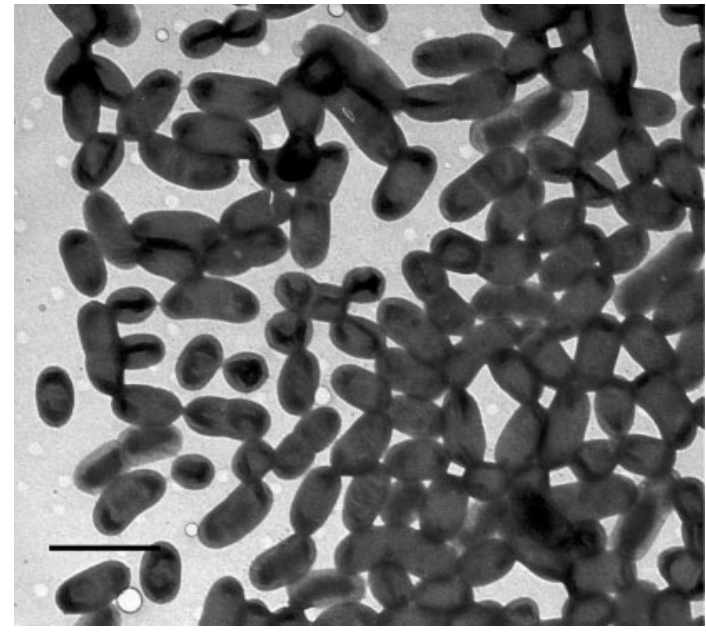

Fig. 1. Transmission electron micrograph of cells of strain R2A15-11 ${ }^{\top}$. Bar, $2 \mu \mathrm{m}$.

After cultivation of R2A $15-11^{\mathrm{T}}$ on $\mathrm{R} 2 \mathrm{~A}$ at $28^{\circ} \mathrm{C}$ for $48 \mathrm{~h}$, the whole-cell fatty acids were analysed according to Sasser (1990). Isoprenoid quinones were examined according to Groth et al. (1996). The G+C content of the DNA was determined as described by Mesbah et al. (1989), using a reversed-phase column (Supelcosil LC-18-S; Supelco).

Genomic DNA extraction, PCR-mediated amplification of the $16 \mathrm{~S}$ rRNA gene and sequencing of PCR products were carried out as described by Kwon et al. (2003). The 16S
rRNA gene sequences were aligned using the CLUSTAL W program (Thompson et al., 1994). A phylogenetic analysis was performed using the software package MEGA (version 3.1) (Kumar et al., 2004). Distances (using distance options according to the Kimura two-parameter model) and clustering (using the neighbour-joining method) were determined by using bootstrap values based on 1000 replicates.

The cultural and metabolic properties of strain R2A15-11 ${ }^{\mathrm{T}}$ are indicated in Table 1 and in the genus and species descriptions. Analysis of quinone compounds revealed MK-7 to be the major isoprenoid quinone. The cellular fatty acids of R2A15-11 ${ }^{\mathrm{T}}$ were iso- $\mathrm{C}_{15: 0}(33.7 \%)$, iso- $\mathrm{C}_{15: 1}$ $\mathrm{G}(22.3 \%)$, iso- $\mathrm{C}_{17: 0} 3-\mathrm{OH}(15.5 \%)$, summed feature 3 (10.6\%; comprising iso- $\mathrm{C}_{15: 0} 2-\mathrm{OH}$ and/or $\mathrm{C}_{16: 1} \omega 7 c$ ), $\mathrm{C}_{16: 0}(3.5 \%)$, iso- $\mathrm{C}_{15: 0} 3-\mathrm{OH}(2.9 \%), \mathrm{C}_{16: 0} 3-\mathrm{OH}(2.4 \%)$, anteiso- $\mathrm{C}_{15: 0}(1.6 \%)$ and an unknown fatty acid $(1.2 \%$; equivalent chain-length 16.582). The DNA G $+\mathrm{C}$ content of strain $\mathrm{R} 2 \mathrm{~A} 15-11^{\mathrm{T}}$ was $45.0 \mathrm{~mol} \%$.

The predominance of MK-7 and the large amounts of fatty acids iso- $\mathrm{C}_{15: 0}$, iso- $\mathrm{C}_{15: 1} \mathrm{G}$, iso- $\mathrm{C}_{17: 0} 3-\mathrm{OH}$ and summed feature 3 (comprising iso- $\mathrm{C}_{15: 0} 2-\mathrm{OH}$ and/or $\mathrm{C}_{16: 1} \omega 7 \mathrm{c}$ ) in strain R2A15-11 ${ }^{\mathrm{T}}$ are features similar to those of members of the genera Terrimonas (Xie \& Yokota, 2006; Weon et al., 2006) and Niastella (Weon et al., 2006) (see Supplementary Table S1, available in IJSEM Online). The DNA G+C content $(45.0 \mathrm{~mol} \%)$ falls within the range (44.3$48.9 \mathrm{~mol} \%$ ) encompassed by the members of the genera Terrimonas and Niastella.

Table 1. Phenotypic comparisons among $\mathrm{R} 2 \mathrm{~A} 15-11^{\top}$ and related strains

Strains: 1, R2A15-11 ${ }^{\mathrm{T}}$; 2, T. ferruginea IAM $15098^{\mathrm{T}}$ (data from Xie \& Yokota, 2006; Weon et al., 2006); 3, T. lutea IAM 15284 ${ }^{\mathrm{T}}$ (Xie \& Yokota, 2006); 4, Niastella koreensis KACC $11465^{\mathrm{T}}$ (Weon et al., 2006); 5, Niastella yeongjuenesis KACC 11466 ${ }^{\mathrm{T}}$ (Weon et al., 2006). + , Positive; -, negative; W, weakly positive; ND, not determined. All strains are positive for gelatin hydrolysis, negative for urea hydrolysis and possess MK-7 as the major menaquinone.

\begin{tabular}{|c|c|c|c|c|c|}
\hline Characteristic & 1 & 2 & 3 & 4 & 5 \\
\hline Cell size $(\mu \mathrm{m})$ & $0.7-0.9 \times 1.0-1.5$ & $0.3-0.5 \times 1.0-3.0$ & $0.3-0.5 \times 1.0-3.0$ & $0.4-0.5 \times 10-50$ & $0.4-0.6 \times 10-40$ \\
\hline Catalase/oxidase & $+1-$ & $\mathrm{w} /+$ & $\mathrm{w} /+$ & $-1-$ & $-1+$ \\
\hline Gliding motility & - & - & - & + & + \\
\hline Colony colour & Orange & Salmon red & Yellow & Light yellow & Milky \\
\hline $\begin{array}{l}\text { Highest } \mathrm{NaCl} \text { concentration } \\
\text { tolerated }(\%)\end{array}$ & 3.0 & 1.0 & 1.0 & ND & ND \\
\hline \multicolumn{6}{|l|}{ Hydrolysis of: } \\
\hline Starch & - & $+^{*}$ & ND & - & - \\
\hline Chitin & - & - & - & + & + \\
\hline
\end{tabular}

${ }^{\star}$ Data from Weon et al. (2006). 
The sequence analyses confirmed the affiliation of the novel isolate with the members of the phylum Bacteroidetes (Fig. 2). Strain R2A15-11 ${ }^{\mathrm{T}}$ is related to members of the genera Terrimonas and Niastella. The $16 \mathrm{~S}$ rRNA gene sequence similarity values for strain $\mathrm{R} 2 \mathrm{~A} 15-11^{\mathrm{T}}$ with respect to Terrimonas ferruginea ATCC $13524^{\mathrm{T}}$, Terrimonas lutea $\mathrm{DY}^{\mathrm{T}}$, Niastella yeongjuensis $\mathrm{GR} 20-13^{\mathrm{T}}$ and Niastella koreensis GR20-10 ${ }^{\mathrm{T}}$ were $91.5,90.2,89.9$ and $89.7 \%$, respectively. The highest level of sequence similarity $(97.6 \%)$ for strain R2A15-11 ${ }^{\mathrm{T}}$ was obtained with respect to a cloned $16 \mathrm{~S}$ rRNA gene sequence derived from an activated sludge with an enhanced biological phosphate removal capacity (clone Ebpr2; Liu et al., 2001). All of the other species (with validly published names) showed sequence similarity levels below $89 \%$.

In terms of physiological and biochemical properties, strain R2A $15-11^{\mathrm{T}}$ differed from members of the genera Terrimonas and Niastella in being able to produce catalase, flexirubin and indole. Furthermore, strain R2A15- $11^{\mathrm{T}}$ can be differentiated from members of the genus Terrimonas on the basis of the tolerance of higher $\mathrm{NaCl}$ concentrations and the absence of oxidase and nitrate reduction. In addition, strain R2A15- $11^{\mathrm{T}}$ can be distinguished from Niastella species by the absence of gliding motility, by differences in cellular morphology and by the inability to hydrolyse chitin and cellulose. The characteristics that differentiate strain $\mathrm{R} 2 \mathrm{~A} 15-11^{\mathrm{T}}$ from other closely related species are listed in Table 1.

On the basis of the results of this polyphasic approach, strain R2A15- $11^{\mathrm{T}}$ represents a novel genus and species, for which the name Niabella aurantiaca gen. nov., sp. nov. is proposed.

\section{Description of Niabella gen. nov.}

Niabella (Ni.a.bel'la. L.L. dim. suff. -ella; N.L. fem. n. Niabella arbitrary name, after NIAB, National Institute of Agricultural Biotechnology, where taxonomic studies of this taxon were conducted).

Cells are Gram-negative, strictly aerobic, non-flagellated, non-spore-forming, short rods. When grown on R2A plates, colonies are orange and circular. Catalase-positive and oxidase-negative. Gliding motility is not observed.
Flexirubin pigment is produced. The predominant isoprenoid quinone is MK-7. The major fatty acids are iso- $\mathrm{C}_{15: 0}$, iso- $\mathrm{C}_{15: 1} \mathrm{G}$, iso- $\mathrm{C}_{17: 0} 3-\mathrm{OH}$ and summed feature 3 (comprising iso- $\mathrm{C}_{15: 0} 2-\mathrm{OH}$ and/or $\mathrm{C}_{16: 1} \omega 7 \mathrm{c}$ ). Phylogenetically, the genus is a member of the phylum Bacteroidetes. The type species is Niabella aurantiaca.

\section{Description of Niabella aurantiaca sp. nov.}

Niabella aurantiaca (au.ran.ti.a'ca. N.L. fem. adj. aurantiaca orange-coloured).

In addition to the properties described above for the genus, the following properties are observed. Cells are approximately $0.7-0.9 \mu \mathrm{m}$ wide and $1.0-1.5 \mu \mathrm{m}$ long. Growth occurs with $\mathrm{NaCl}$ concentrations in the range $0-3 \%(\mathrm{w} / \mathrm{v})$ (optimum, 1-2\%), at temperatures between 10 and $35^{\circ} \mathrm{C}$ (optimum, $25-30^{\circ} \mathrm{C}$ ) and at $\mathrm{pH} 5.0-8.0$ (optimum, $\mathrm{pH}$ 6-7). Casein and tyrosine are hydrolysed. Alginic acid, chitin, carboxymethylcellulose, DNA and starch are not hydrolysed. Positive for indole production, aesculin hydrolysis and $\beta$-galactosidase, but negative for nitrate reduction, glucose fermentation, arginine dihydrolase, urease and gelatin hydrolysis (API 20NE). Positive for alkaline phosphatase, esterase (C4), esterase lipase (C8), leucine arylamidase, acid phosphatase, naphthol-AS-BI-phosphohydrolase, $\alpha$-galactosidase, $\beta$-galactosidase, $\alpha$-glucosidase, $\beta$-glucosidase, $\quad N$-acetyl- $\beta$-glucosaminidase, $\alpha$-mannosidase and $\alpha$-fucosidase activities, but negative for lipase (C14), valine arylamidase, cystine arylamidase, trypsin, $\alpha$-chymotrypsin and $\beta$-glucuronidase activities (API ZYM). Assimilates D-glucose, L-arabinose, D-mannose, $N$-acetylglucosamine, D-maltose, L-rhamnose, sucrose, salicin and D-melibiose (API 20NE and API ID 32 GN). Does not assimilate D-mannitol, potassium gluconate, capric acid, adipic acid, malic acid, trisodium citrate, phenylacetic acid, D-ribose, inositol, itaconic acid, suberic acid, sodium malonate, sodium acetate, lactic acid, L-alanine, potassium 5-ketogluconate, glycogen, 3-hydroxybenzoic acid, L-serine, L-fucose, D-sorbitol, propionic acid, valeric acid, L-histidine, potassium 2-ketogluconate, 3-hydroxybutyric acid, 4-hydroxybenzoic acid or L-proline (API 20NE and API ID $32 \mathrm{GN})$. The DNA $\mathrm{G}+\mathrm{C}$ content of the type strain is $45.0 \mathrm{~mol} \%$ (HPLC).

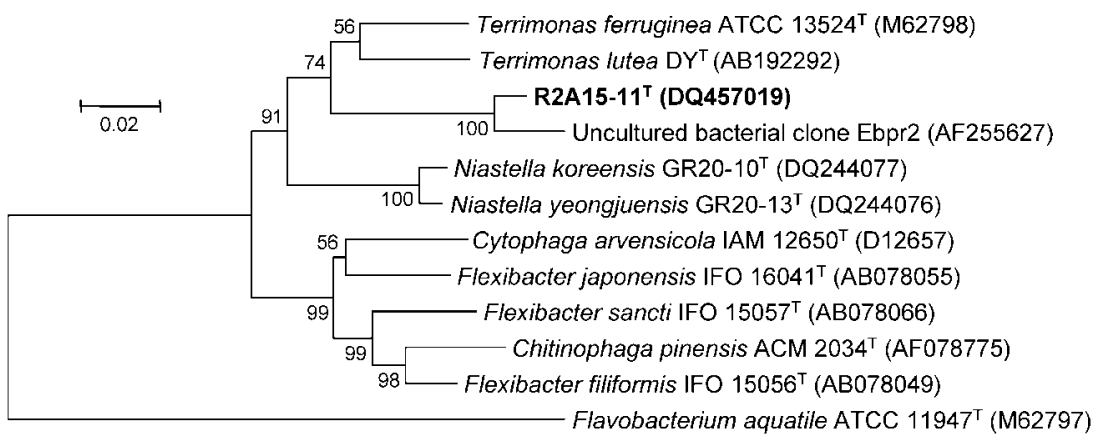

Fig. 2. Neighbour-joining phylogenetic tree for strain $\mathrm{R} 2 \mathrm{~A} 15-11^{\top}$ and related strains, based on almost-complete 16S rRNA gene sequences. Numbers at nodes indicate percentages of bootstrap support based on a neighbour-joining analysis of 1000 resampled datasets. Bar, 2 substitutions per 100 nt. 
The type strain, R2A15-11 ${ }^{\mathrm{T}}$ (=KACC $11698^{\mathrm{T}}=\mathrm{DSM}$ $\left.17617^{\mathrm{T}}\right)$, was isolated from greenhouse soil in Yeoju Region, Republic of Korea.

\section{Acknowledgements}

This study was supported by a programme of international collaborative research between the Rural Development Administration (Suwon, Republic of Korea) and the Deutsche Sammlung von Mikroorganismen und Zellkulturen (Braunschweig, Germany).

\section{References}

Groth, I., Schumann, P., Weiss, N., Martin, K. \& Rainey, F. A. (1996). Agrococcus jenensis gen. nov., sp. nov., a new genus of actinomycetes with diaminobutyric acid in the cell wall. Int J Syst Bacteriol 46, 234-239.

Kumar, S., Tamura, K. \& Nei, M. (2004). MEGA3: integrated software for molecular evolutionary genetics analysis and sequence alignment. Brief Bioinform 5, 150-163.

Kwon, S. W., Kim, J. S., Park, I. C., Yoon, S. H., Park, D. H., Lim, C. K. \& Go, S. J. (2003). Pseudomonas koreensis sp. nov., Pseudomonas umsongensis sp. nov. and Pseudomonas jinjuensis sp. nov., novel species from farm soils in Korea. Int J Syst Evol Microbiol 53, 21-27.

Liu, W. T., Nielsen, A. T., Wu, J. H., Tsai, C. S., Matsuo, Y. \& Molin, S. (2001). In situ identification of polyphosphate- and polyhydroxyalkanoate-accumulating traits for microbial populations in a biological phosphorus removal process. Environ Microbiol 3, 110-122.

Mesbah, M., Premachandran, U. \& Whitman, W. B. (1989). Precise measurement of the $\mathrm{G}+\mathrm{C}$ content of deoxyribonucleic acid by highperformance liquid chromatography. Int J Syst Bacteriol 39, 159-167.
Nakagawa, Y. \& Yamasato, K. (1993). Phylogenetic diversity of the genus Cytophaga revealed by $16 \mathrm{~S}$ rRNA sequencing and menaquinone analysis. J Gen Microbiol 139, 1155-1161.

Nakagawa, Y., Sakane, T., Suzuki, M. \& Hatano, K. (2002). Phylogenetic structure of the genera Flexibacter, Flexithrix, and Microscilla deduced from 16S rRNA sequence analysis. J Gen Appl Microbiol 48, 155-165.

Reichenbach, H. (1992). The order Cytophagales. In The Prokaryotes. A Handbook on the Biology of Bacteria: Ecophysiology, Isolation, Identification, Applications, 2nd edn, pp. 3631-3675. Edited by A. Balows, H. G. Trüper, M. Dworkin, W. Harder \& K. H. Schleifer. New York: Springer.

Sasser, M. (1990). Identification of bacteria by gas chromatography of cellular fatty acids. USFCC Newsl 20, 1-6.

Sly, L. I., Taghavi, M. \& Fegan, M. (1999). Phylogenetic position of Chitinophaga pinensis in the Flexibacter-Bacteroides-Cytophaga phylum. Int J Syst Bacteriol 49, 479-481.

Smibert, R. M. \& Krieg, N. R. (1994). Phenotypic characterization. In Methods for General and Molecular Bacteriology, pp. 607-654. Edited by P. Gerhardt, R. G. E. Murray, W. A. Wood \& N. R. Krieg. Washington, DC: American Society for Microbiology.

Thompson, J. D., Higgins, D. G. \& Gibson, T. J. (1994). CLUSTAL W: improving the sensitivity of progressive multiple sequence alignment through sequence weighting, position-specific gap penalties and weight matrix choice. Nucleic Acids Res 22, 4673-4680.

Weon, H. Y., Kim, B.-Y., Yoo, S.-H., Lee, S.-Y., Kwon, S.-W., Go, S.-J. \& Stackebrandt, E. (2006). Niastella koreensis gen. nov., sp. nov. and Niastella yeongjuensis sp. nov., novel members of the phylum Bacteroidetes, isolated from soil cultivated with Korean ginseng. Int J Syst Evol Microbiol 56, 1777-1782.

Xie, C. H. \& Yokota, A. (2006). Reclassification of [Flavobacterium] ferrugineum as Terrimonas ferruginea gen. nov., comb. nov., and description of Terrimonas lutea sp. nov., isolated from soil. Int J Syst Evol Microbiol 56, 1117-1121. 